\title{
Lymphedema, CTCAE
}

National Cancer Institute

\section{Source}

National Cancer Institute. Lymphedema, CT CAE. NCI Thesaurus. Code C143660.

A disorder characterized by excessive fluid collection in tissues that causes swelling. 